\title{
Moderating Effects of Dynamic Managerial Capabilities on Heterogeneous Workplaces: A Case Study of Private Banks in Egypt
}

\author{
Said Sayed Shabban Abdo Sayed ${ }^{1} \&$ David Edgar ${ }^{2}$ \\ ${ }^{1}$ School of Marketing and Management, AL Nahda University (NUB), New Bani Sweif City, Egypt \\ ${ }^{2}$ Strategy \& Business Transformation, Department of Business Management, Glasgow School for Business and \\ Society, Glasgow Caledonian University, Glasgow, Scotland, United Kingdom \\ Correspondence: David Edgar, Professor, Strategy \& Business Transformation, Department of Business \\ Management, Glasgow School for Business and Society, Glasgow Caledonian University, Cowcaddens Road, \\ Glasgow, G40BA, Scotland, United Kingdom.
}

Received: March 14, 2019

Accepted: March 30, 2019

Online Published: April 3, 2019

doi:10.5430/ijba.v10n3p23

URL: https://doi.org/10.5430/ijba.v10n3p23

\begin{abstract}
Purpose - The purpose of this study is to present strategies that banking organizations might adopt to utilize the heterogeneity and generational differences for better workplaces. Workforce diversity has been identified as one of the strategic capabilities that will add value to the organizations over their competition. As one of the most globally competitive sectors, the banking industry faces the challenge of attracting highly skilled and extremely innovative employees while retaining valuable senior employees to make use of their expertise in an inclusive setting. . As such, an understanding of heterogeneity and generational differences may be used as a tool by managers to improve employee productivity, innovation and to create good corporate individuals. Data was collected from a target population from seven general managers of private banks operating in Egypt who were managing through the multigenerational phenomenon. The paper will utilize the Resource-based view (RBV) framework as a complementary theory based on the assumption that organizations differ according to the heterogeneity of their resources.

Design/methodology/approach - This study adopts a qualitative approach and presents findings based on a series of semi-structured interviews with senior managers of the Private Banks operating in Egypt.

Findings - The findings show that resource idiosyncrasy, deployment, utilizations and organizational culture accommodate dynamic managerial capabilities (DMC) to achieve sustainable competitive advantage (SCA) in the multigenerational heterogeneous workplace. By analysing the components of the VIRO model that reviews resource characteristics that could lead to sustain competitive advantage, the findings of the current research revealed DMC as an underestimated moderator for achieving the SCA.

Practical implications - The practical implication of this study is to extend generational research by investigating the effect of inclusion and the importance different generations place on the presence of various workplace characteristics. Organizations are exploring the inclusion of workforce diversity against the traditional structure. A private bank's workforce has employees from different countries, cultures, generations and genders. This heterogeneity has positioned private banks as a striking foreign investment destination due to their mature and experienced workforce. Managerial capabilities and skills can utilize the challenges resulting from such wider heterogeneity in a multidisciplinary approach for achieving sustained competitive advantages. Thus, workforce heterogeneity is regarded as an asset for private banks for connecting with businesses all over the world and for enabling foreign communities to conduct their business within its location.

Originality/value - The paper originated from the researchers' own unique investigation into the employment market from a managerial standpoint. Little qualitative research has been thus far published regarding how organizations hire highly skilled and extremely innovative people to work while maintaining old employees to make use of their expertise in an inclusion setting. Particularly, the notion of adapting a Resource -Based View to illustrate how heterogeneity and generational differences may be used as a tool by managerial capabilities to improve employee productivity, innovation and to create good corporate individuals is also a new area for academic research.
\end{abstract}

Keywords: resource - based view, capabilities, banks, multigenerational, SCA 


\section{Introduction}

For the first time in history, five generations that have each been raised under different social circumstances and characterised by different sets of values, beliefs and traits will be working side by side (Knight 2014). This multigenerational mix gives new meaning to diversity and highlights not only an opportunity to work with each other but also a new understanding of diversity (Crampton and Hodge 2007; Kuron 2012). While multigenerational perspectives can help companies' decision-making processes and increase responsiveness to customers, it also creates complex human resource policies for meeting employees' needs, once cohorts aspire multi-needs from their workplace environment (Mencl et al. 2014.p.258). Generational differences can also lead to negative organisational outcomes, such as conflict, misunderstanding and miscommunication that exist among employees in the workplace (Jurkiewicz 2000; Smola and Sutton 2002).

In contrast, understanding generational differences allows managers to improve employee productivity and innovative thinking and to create good corporate citizens (Kupperschmidt 2000). Business managers should seek successful strategies for addressing these challenges in to cope with the people having work styles, motivations, divergent work principles, understandings, and mentalities and should value differences to ensure efficient operations, organisational success and atmospheres of inclusion, in which every employee can thrive and work towards common goals (Gupta et al. 2013).

Many employees are choosing to work past 60-70 years of age; thus, Baby Boomer, Generation X and Millennial cohorts will continue to work alongside each other for another decade or more (Mencl and Lester 2014.p.258). A workforce consisting of diverse employee perspectives and experiences can provide creative business solutions due to the combination of 'novel information and perspectives, leading to better decision-making and problem solving' (Caleb 2014, p. 44); however, firms do not effectively utilise heterogeneity among the talents of older generations of workers due to false assumptions and stereotypes that they are expensive, prone to health problems, unable to adapt to workplace changes and new technology, perform poorly in comparison to younger employees and are a poor return on training investments (Darwin and Palanisamy, 2015.p.18-19). Instead, organisations should retain valuable senior employees whilst recruiting bright young talent (Woodward et al. 2015), which depends on understanding employees' differing development, reward requirements and training needs to motivate different generational cohorts (Beechler and Woodward 2009). An organisation's ability to harness the power of a diverse workforce to realise tangible benefits is known as inclusion. In an inclusive working environment, diverse employees demonstrate cultural competences by understanding and successfully collaborating with each other to produce ideas and offer perspectives.

This study applied the firm resource-based view (RBV), which is a well-established approach for strategic management and business studies (Wan et al. 2011), because it is commonly used in strategic management literature, accommodates new theoretical insights and its ability to be integrated well with other perspectives (Barney, Ketchen and Wright, 2011.p.1303). The fundamental principle of the RBV is that an organisation's competitive advantage depends predominately on deploying, assigning roles and orchestrating these different cohorts of employees as bundled resources in the workplace. Barney (2002) presumed that these bundles resource as heterogeneous resources and that some of them are pricy to be duplicated. The research use bundle as a metaphor for dissimilar cohorts of employees bundled and coexisting in the same workplace; in this research, the RBC was used to describe and analyse the selection, accumulation and deployment of firms' resources in relation to competitiveness. A research gap in organisational deployment of resources and resource-capability bundles to increase or maintain competitive advantages was investigated by examining how managers of private banks in Egypt manage multigenerational employees to create adaptive workplaces.

\subsection{Research Purpose}

The purpose of this research is as follows:

1. To investigate how managers of private banks in Egypt deploy resources, capabilities and resource-capability bundles (heterogeneous workforces) to increase or maintain sustained competitive advantages in the rapidly changing banking industry.

2. To define how private banks in Egypt create specific policies and organisational environments to support bundled resources that foster unique organisational character.

3. To apply the RBV as a theoretical framework to explore how banks utilise employees' heterogeneity to increase or maintain competitiveness. 
4. To provide complementary insights in response to the many scholars who have called for a more qualitative understanding of generational phenomena (Joshi et al. 2011; Lyons and Kuron 2014; Woodward et al. 2015) to support theoretical developments for multigenerational diversity.

\section{Literature Review}

\subsection{Generations in the Workplace}

In studies on the influence of populations on society, the term 'generation' denotes a group born and raised during the same time period (Gursoy et al. 2013). Kupperschmidt (2000) defined a generation as a recognisable cluster of people who share significant life events, birth years, ages and locations. Studies suggest that the morals of a generation are likely influenced by social and historical experiences during childhood (Smola and Sutton 2002). Despite dissimilarities, generations identify with their shared history and reflect this in similar behaviours (Beldona et al. 2008). Thus, managers should seek to understand the characteristics of multigenerational groups (Cummings et al. 2013). According to Gursoy et al. (2013), the three generations currently represented in the workplace are Baby Boomers, Generation X and Millenials (i.e., Generation Y).

\subsubsection{Baby Boomers}

Born between 1946 and 1964, Baby Boomers form the largest generational group due to the birth of an additional 17 million children after World War Two, compared to pre-war birth rates (Bureau of Labor Statistics in AARP 2007; O’Bannon 2001). Baby Boomers account for 77 million employees in the current United States (US; Kilber, Barclay and Ohmer 2014). Raised in an era of hopefulness and financial good fortune, these employees are committed to lifetime employment and company loyalty, working hard to gain benefits for their personal life and prioritising family welfare (Zeeshan and Iram 2012; Eversole et al. 2012). Identified as goal-oriented individuals, this characteristic is important when managing inter-generational conflicts because Baby Boomers assume that other employees have the same work ethic and work the same hours. In addition, Baby Boomers are results driven, dedicated and acknowledge hierarchical structures in workplaces (Gursoy et al. 2013).

\subsubsection{Generation X}

The group born between 1965 and 1979 forms the smallest generational group, making up 18\% of the workforce in the United states (Normala and Dileep 2013; Berk 2013). The designation of X indicates the absence of clear distinctive features for this group (Brown 2012), although this generation is the first cohort to grow up with personal computers, cell phones and other electronic devices (Young et al. 2013). Generation X lives in contradiction to Baby Boomers and focus on maintaining good physical health and work-life equilibrium (Debevec et al. 2013). Such individuals are knowledgeable and self-governing philosophers, placing more value on family and associates than on work (Young et al. 2013). As workers, Generation X prefers consequences based on evidence rather than sentiments, and according to Hendricks and Cope (2012), this generation is technologically savvy, easy-going, and welcoming of diversity. The Generation X workforce values workplace independence and truthful and respectful supervisors (Cekada 2012).

\subsubsection{Millennials (Generation Y)}

Millennials are the most recent generational group, consisting of 76 million employees in the United States born between 1980 and 1990 (Murphy, 2012). The millennial cohort grew up with the internet, which influenced their ethical standards. Millennial's technological and intellectual capability sets them apart from previous generational cohorts, especially in relation to electronic communication and a focus on individual development (Debevec et al. 2013; Al-Asfour and Lettau, 2014). Millennials dislike the inflexibility of eight to five work days; however, research recommends that this cohort requires continuous observation and direction from those with proficient knowledge comprising both Baby Boomers and Generation X in the workplace, because they value informality (Burke, 2004).

\subsection{Generational Differences and Challenges in the Workplace}

Generational differences are often used as organisational tools, such as in marketing to measure consumer segmentation (Noble and Schewe 2003). In particular, the generational differences between Baby Boomer and Generation X employees have been widely studied (Cennamo and Gardner 2008; Twenge et al. 2010; Gursoy et al. 2013). Although some researchers have observed little differentiation between each generation's work values (Eskilson and Wiley 1999), other researchers have determined that work values are 'more influenced by generational experiences than by age and maturation' and that such variances should be understood to ensure effective communication and employee motivation and development (Smola and Sutton 2002). Because political, social and 
cultural issues affect individual values and work ethic, managers must understand, manage and train multigenerational workforces that contain diverse values, styles of learning and expectations (Cekada 2012.p.42).

\subsubsection{Technology}

Cekada (2012) posited that technology is the principle barrier among multigenerational workforces in terms of communication. Cited in (Cekada ,2012.p.41) that, according to a Pew Research Centre survey, 75\% of adults between 18 and 30 use the internet daily compared to four in ten adults aged 65-75. As Behrstock-Sherratee and Coggshall (2010) suggested, '[t]he older Gen X goes online to accomplish a task and then walks away from the computer. Gen Y goes online and offline seamlessly and does not make a distinction between one and the other'. Beyers (2009) found that Generation Y expect instant responses to e-mails or text messages, prioritising response speed over message content, leading to other cohorts perceiving Generation Y as hasty; however, they are often capable multitaskers who can shift easily from one action to another (Cekada 2012).

\subsubsection{Communication}

Behrstock-Sherratee and Coggshall (2010) suggested that people learn to communicate based on generational backgrounds, which also influences technology use and social interactions through messaging, blogging, texting and e-mails, although older generations perceive these activities to be purposelessly. Understanding similarities and differences among generational groups and adopting appropriate management practices for each member of a multigenerational workforce is likely to create a workplace environment that foster leadership, motivation, communication and generational synergy (Gursoy et al. 2013.p.40). For example, if Generation X values autonomy, work may need to be redesigned to increase their freedom and independence on the job; similarly, if Generation Y is committed to socially responsible causes, organisations may need to pay more attention to corporate social responsibility (Woodward et al. 2015). Leveraging generational strengths can yield tremendous organisational benefits, such as increasing morale, controlling costs, reducing turnover and improving sales and profits (Lancaster and Stillman 2002). The current research identifies similarities and differences among generational groups in the workplace and how employee heterogeneity can be utilised through employees' dynamic capabilities to sustain competitive advantages.

\section{Methodology}

\subsection{Research Method and Design}

This study employed qualitative inquiry to explore approaches to managing multigenerational workforces in private banks in Egypt.

\subsubsection{Participants}

Purposeful sampling is a common technique in qualitative research to classify and choose well-informed and knowledgeable; in the current study, a focused sample of seven managers from private banks in Egypt was selected (Table 1). The researcher provided informed consent letters, which were signed by each participant to ensure that they understood and consented to the research. Individual arrangements were made for interviews to ensure privacy, convenience and participant availability.

\subsubsection{Data Collection Instruments}

Semi-structured, face-to-face interviews were used to investigate manager's approaches to managing multigenerational workforces at private banks in Egypt.

\subsection{Data Analysis}

Thematic analysis was conducted to cluster and convert a large amount of data into coded themes by categorising related theme and subject patterns (Neuendorf 2002). Jennings et al. (2015) recommended that researchers focus on coding and classifying data into such categories to establish facts and theoretical elements. Because the interview data was manageable without using software packages, coding was performed manually.

Table 1. Seven interviewees at private banks in Egypt

\begin{tabular}{lllllllllll}
\hline No. Name & Gender & Nationality & $\begin{array}{l}\text { Job } \\
\text { Title }\end{array}$ & Profession & Location & $\begin{array}{l}\text { Interview } \\
\text { Duration in } \\
\text { minutes }\end{array}$ & Profile & $\begin{array}{l}\text { Additional } \\
\text { Skills }\end{array}$ \\
\hline 1 & A D & Male & Egyptian & GM & Aud & Cairo & 46 & 26 & years' & English / \\
\hline
\end{tabular}




\begin{tabular}{|c|c|c|c|c|c|c|c|c|c|}
\hline & & & & & & & & $\begin{array}{l}\text { experience } \\
\text { in Banking } \\
\text { industry }\end{array}$ & $\begin{array}{l}\text { computer } \\
\text { programing }\end{array}$ \\
\hline 2 & M A & Male & Egyptian & GM & $\mathrm{CA}$ & Cairo & 45 & $\begin{array}{l}4 \text { years' } \\
\text { experience } \\
\text { in Banking } \\
\text { industry }\end{array}$ & $\begin{array}{l}\text { English/ } \\
\text { French }\end{array}$ \\
\hline 3 & D B & Male & Egyptian & GM & NBK & Cairo & 50 & $\begin{array}{l}23 \text { years' } \\
\text { experience } \\
\text { in Banking } \\
\text { industry }\end{array}$ & $\begin{array}{l}\text { English/ } \\
\text { Finance } \\
\text { developer }\end{array}$ \\
\hline 4 & B G & Male & Egyptian & GM & DU Ca & Cairo & 42 & $\begin{array}{l}35 \text { years' } \\
\text { experience } \\
\text { in Banking } \\
\text { industry }\end{array}$ & $\begin{array}{l}\text { English } \\
\text { /PhD } \\
\text { Finance } \\
\text { \&Banking }\end{array}$ \\
\hline 5 & W H & Male & Egyptian & GM & EALB & Cairo & 40 & $\begin{array}{l}19 \text { years' } \\
\text { experience } \\
\text { in Banking } \\
\text { industry }\end{array}$ & $\begin{array}{l}\text { English/ } \\
\text { soft skills }\end{array}$ \\
\hline 6 & $\begin{array}{l}\mathrm{M} \\
\mathrm{SH}\end{array}$ & Male & Egyptian & GM & $\mathrm{CA}$ & Cairo & 51 & $\begin{array}{l}11 \text { years' } \\
\text { experience } \\
\text { in Banking } \\
\text { industry }\end{array}$ & $\begin{array}{l}\text { English/ } \\
\text { French/ } \\
\text { Germany }\end{array}$ \\
\hline 7 & A B & Male & Egyptian & GM & AAIB & Cairo & 40 & $\begin{array}{l}13 \text { years' } \\
\text { experience } \\
\text { in Banking } \\
\text { industry }\end{array}$ & $\begin{array}{l}\text { English/ } \\
\text { Financial } \\
\text { Expert }\end{array}$ \\
\hline
\end{tabular}

\subsection{Conceptual Framework}

The RBV is the most commonly used framework in strategic management for studying inter-firm heterogeneity because relies on the fact that competitive advantage is dependent on the unique heterogeneous resources of individual firms (Lockett et al. 2009; Newbert 2007). Penrose (1959) stated that 'heterogeneity ... of the productive services available or potentially available from ... resources ... gives each firm its unique character' (p. 75), while Barney (1991) found that heterogeneous resources and capabilities create sustainable competitive advantages (SCAs) and should to be the foundation of a firm's competitive strategy. The four essential criteria for such resources and capabilities are known as the valuable, rare, imperfectly imitable and non-substitutable (VRIN) framework (Barney 1991). Resources that improve efficiency and effectiveness by utilising opportunities or neutralising threats are valuable; resources that are not controlled by rival organisations are; resources that are impossible or problematic for rivals to imitate are imperfectly imitable; and resources that have unique strategic value are non-substitutable. Barney (1991) further modified the VRIN framework to valuable, rare, imperfectly imitable and organisation (VRIO), which is the environment in which resources and capabilities are identified to achieve SCAs (Kozlenkova et al. 2014). Organisations must be able to recognise a VRIN resource or capability and be prepared to exploit it; in particular, recording, structural and managerial control systems are essential internal resources and capabilities (Figure 1; Barney and Delwyn 2007). 


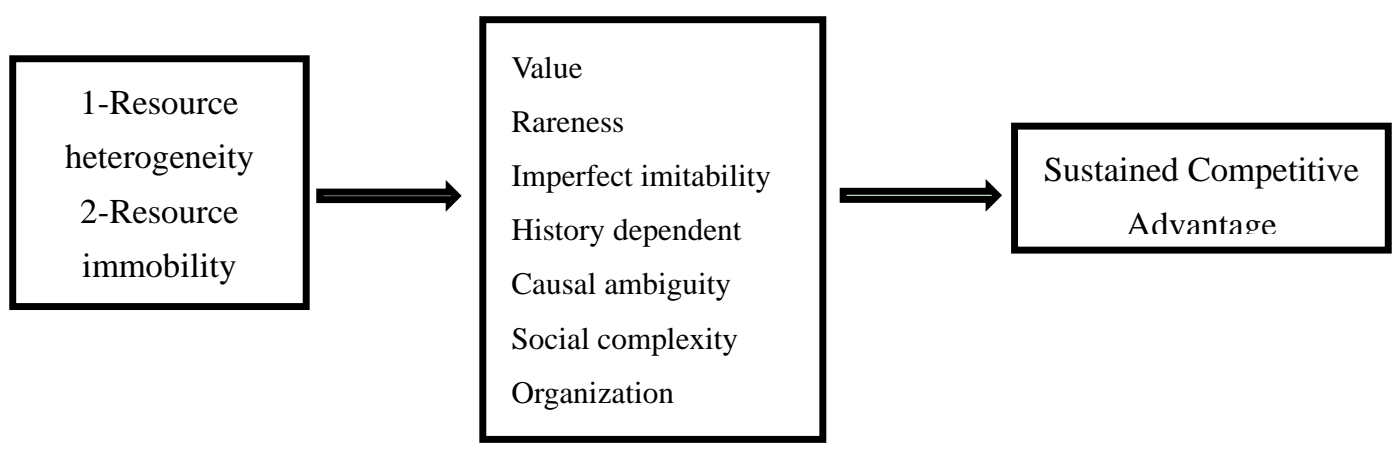

Figure 1. The relationship between the core assumptions of the VRIO framework for SCA (Barney and Delwyn 2007)

For an organisation to benefit from its VRIN resources, it must be able to utilise these resources (Barney 1997). However, when changes are quick and unpredictable, such as changes at private banks in Egypt, the RBC does not provide sufficient solutions for creating organisational competitive advantages. In rapidly changing work environments, dynamic capabilities provide SCAs (Teece et al. 1997). Kozlenkova et al. (2014) define such capabilities as 'resources that can be used to modify other resources and create value. Examples include product development routines, transfer processes, resource allocation routines, alliance and acquisition capabilities, and knowledge creation processes' (p.5). However, Peteraf and Barney (2003) found that 'the dynamic capabilities literature is entirely consistent with RBV and should not be viewed as a separate theory' (p. 321). The significance of dynamic capabilities for competitive advantages resides in the adaption of resource bases to generate new value-creating strategies; thus, organisational performance is grounded in dynamic managerial capabilities (DMC) that ensure competitive advantages based on strategic, heterogeneous and unique organizational assets that are difficult to emulate (Beck and Wiersema 2013; Acosta et al. 2011). Consequently, the uniqueness of assets has important effects on the success, competence, sustainability and competitiveness of banks.

The purpose of the RBV is to understand managerial strategic resources because firms' abilities to acquire, bundle, deploy and develop resources through complex social and organisational capabilities is more important than absolute resource levels to achieving SCA and to driving performance (Teece 2007; Maritan and Peteraf 2011; Sirmon et al. 2011). Research on the application of the RBC to identify organisational capabilities and skills among multigenerational employees with heterogeneous assets to acquire, bundle, deploy and develop these resources for SCA is interesting and underexplored. (Maritan and Peteraf 2011) Thus, this research offers valuable information to help human resource and banking managers improve the effectiveness of recruitment processes and pertinent principles for managing multigenerational workplaces effectively.

\section{Findings and Discussion}

The capabilities of managers at private banks in Egypt to manage multigenerational employees as heterogeneous assets for achieving SCA were examined using the RBV lens and the VRIO framework. While analysing seven private banks, sources supporting bank capabilities as primary resources were categorised as human capital, organisational culture and DMC. When combined, deployed and integrated into managerial capabilities, these resources create economic because they cannot be replicated by other firms. Thus, managerial dynamic capabilities are indispensable for organising, configuring and deploying heterogeneous multigenerational resources to achieve SCA.

\subsection{Analysis of the Vrio Model}

\subsubsection{Theme 1: Human Capital}

The subthemes within this section emphasise the importance of human capital resources as valuable, rare and inimitable and how organisational support forms the basis achieving competitive advantage. The VIRO analysis in Table 2 emphasises that once resources have passed the VIRO criteria, they are combined or deployed to incur benefits and to generate persistent SCA. 
Table 2. The importance of human capital

Key concept $\quad$ Key studies $\quad$ Key findings

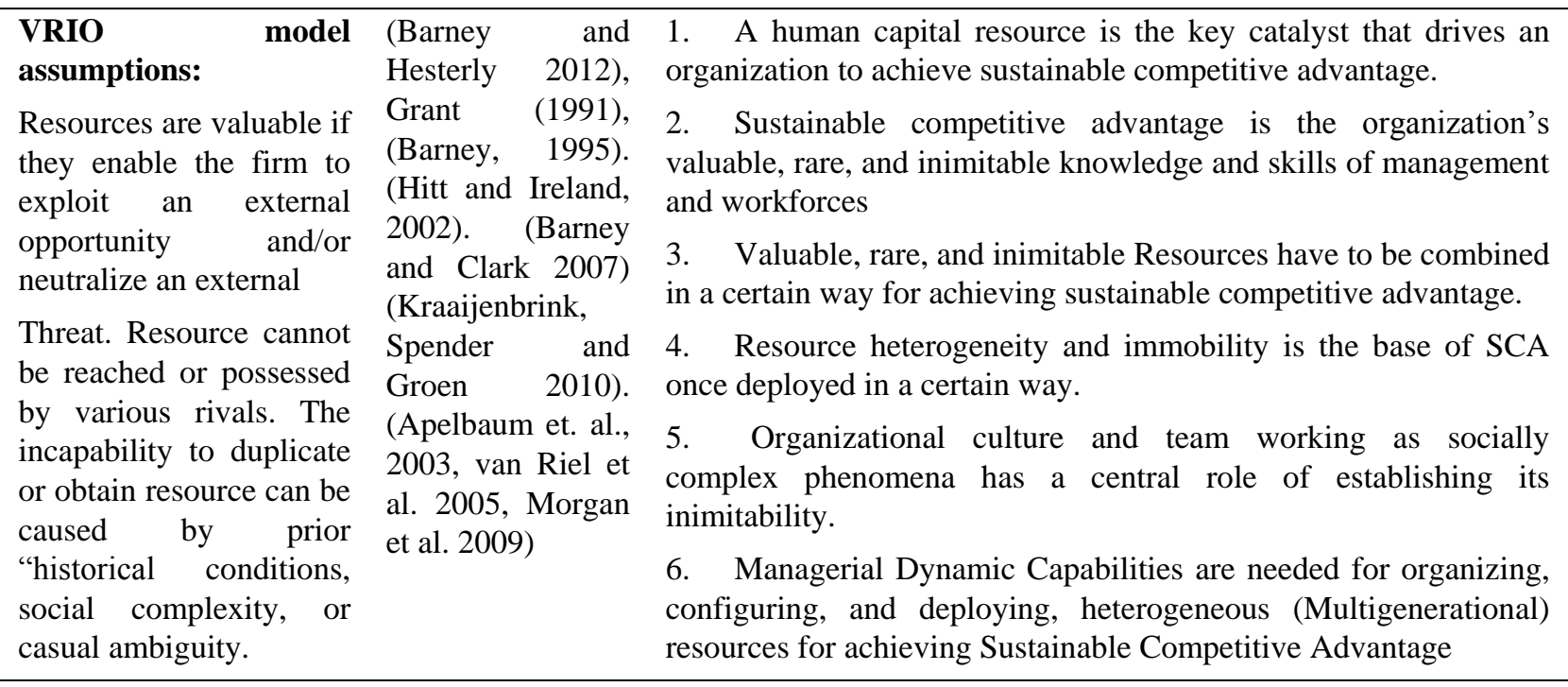

Analysis of managers' interviews revealed that human capital resources are regarded as valuable, rare and inimitable and can thus be used to achieve SCA when implementing the RBV. These resources enable banks to exploit external opportunities and neutralise external threats and are not possessed by competing firms, making them difficult for rivals to duplicate.

\subsubsection{Value}

Our experienced employees enable us to maintain our customer loyalty, dominate in the industry with the best service and employees and avoid threats, in terms of losing our customers to other banks. So, our employees from different cohorts have to work together successfully to confront any threats from our counterparts and rivals. (AD)

The capabilities of our employees to develop themselves by learning recent technology facilities to remain competitive with their young colleagues, respond to demands of the recent market developments in order to not be replaced by newly younger employees. (MA)

We have the most knowledgeable staff. I guess this is the reason that we are still the top bank in Egypt and outperform our counterparts and increase our profits. (BG)

Our staffs' endeavours to keep our customers' loyalty attract them from other banks and enlarge our customer network; thus, [we] dominate the market and avoid customer loss. (WH)

According to the above transcripts, human resources constitute a valuable advantage among banks' capabilities to provide innovative creative solutions for customers to maintain loyalty, optimal services and customer service and to avoid losing customers to rivals and being replaced by banks utilising new technology. In addition, human capital was deemed a valuable resource because it allows certain banks to dominate the market and increase profits. These themes corroborate the results of Apelbaum et al. (2003), van Riel et al. (2005) and Morgan et al. (2009), who found that human capital is a valuable resource that increases productivity, lowers the cost of capital, intensifies client loyalty and reduces customer defection. Barney and Arikan (2001) and Barney and Hesterly (2012) also found that human resources are valuable because they allow firms to implement strategies that have the effect of decreasing a firm's net costs and/or escalating a firm's net revenues beyond what would have been the case without these resources. (p. 138).

\subsubsection{Rarity}

We have a very strong HR team, we do service. Therefore, if you cannot find it here, you will go to another bank. (AD)

Teamwork skills are an important asset in our staff. (BG) 
Because of our skilled and collaborated staff, we are unique and remain competitive in the market. (WH)

The respondents of the interviews confirmed that not only were human capital resources rare and exclusive to each bank but also knowledgeable, skilled, unique, well-bonded and one of the main reasons for competitive advantages in the market. These findings confirm the results of previous research that, according to the RBV, once a resource or capability is deemed to be valuable and rare, it can be categorised as a competitive advantage (Barney and Delwyn 2007). Since these rare resource were controlled only by private banks in Egypt, human capital differs among private banks in other markets (Makadok 1999), which was confirmed by managers reporting that other banks do not have or have limited resources (Kozlenkova et al. 2014).

\subsubsection{Imperfect Imitability}

\subsection{Casual Ambiguity}

The bank was number 39, but now we are number eight, and we are working with more competitive employees to obtain more dominance in the market. (AD)

I like to be involved in solving problems that may arise during the day in order to facilitate our customer services, maintain customers' loyalty to our bank and also guide with tuitions the young employees when solving business problems so as to gain competitive advantage. (MA)

We rely on operationalising, transferring and conveying the accumulated experience from the old to young staff. (MSH)

\subsection{Social Complexity}

We are implementing our assigned tasks accurately as we are dealing with other people's money. (AB)

We trust in their skills, and based on this, our customers trust us. (WH)

Young employees defer to their elder division managers for explanations. (AB)

\subsection{Heterogeneity}

It is a must to have heterogeneous multigenerational employees so that young [employees] learn from older [employees]. (AD)

A multigenerational workplace is the most beneficial place to work because you manage people [who have] different perspectives. (MA)

Our multigenerational workforce is the most valuable, rare, creative and knowledgeable asset among our assets. (DB)

However, there are differences actually among our multigenerational employees in terms of technology [skills], ethics, work commitments, values, etc. (WH)

From a managerial perspective, causal ambiguity relates to reasons for market dominance, which enables banks to obtain higher rankings, to facilitate customer services, to maintain customer loyalty and to assist young employees to solve business problems to gain competitive advantage. In addition, the respondents related causal ambiguity to transference of tacit knowledge from managers to subordinates. These findings corroborate the findings of Barney and Clark (2007) that resources are imperfectly imitable because of unique historical conditions, causal ambiguity or social complexity. Causal ambiguity can include tacit knowledge embedded in relational resources, organisational learning and dynamic capabilities (Crook et al. 2008; Levitt and March 1988; Zollo and Winter 2002).

Social complexity is linked to cultural, institutional and organisational contexts and generates resource bundling as a way of utilising intangible or invisible assets (Peng and Meyer 2011). Respondents also stated that employees had a high level of accountability towards their assigned tasks and mutual trust with customers, with young employees deferring to their peers for explanations. These are socially complex interactions that are very difficult to imitate by rival banks. These findings confirm the results of Barney and Delwyn (2007) that socially complex competitive advantages are difficult to emulate because of various combinations of customer connections, organisational culture and interpersonal relationships.

Heterogeneity is the result of individual organisations' diverse and unique bundling of resources and suggests that some organisations are more capable of achieving particular activities because of distinctive resources (Peteraf and Barney 2003). Managers of private banks in Egypt emphasised the necessity of employing heterogeneous multigenerational employees who can cooperate and encourage each other to learn and embrace multiple perspectives. Thus, heterogeneity is considered the most valuable, rare, creative and knowledge-based of 
organisational assets. These findings confirm those of Peteraf (1993), who concluded that heterogeneity forms the basis for SCA, while Ricardo (1817) defined heterogeneity as “"the sine-qua-none” of competitive advantage'. (p. 185) It has been argued that individual resource value and rareness are not suitable criteria for examine competitive advantage and that resource mixtures carry more promise for contribution to competitive advantage than individual resources and capabilities (Newbert 2008.p.748).

Although heterogeneous multigenerational workplaces contribute to achieving SCA, from the general managers' perspectives, differences appeared among multigenerational employees' attitudes to technology, ethics, work commitment and values. Consequently, understanding these similarities and differences across generational groups and adopting appropriate management practices for each member of a multigenerational workforce is of strategic importance that increases employee morale and productivity by lowering workplace tensions and generational conflicts in the workplace (Gursoy et al. 2013.p.47). As such, DMC are needed for organising, configuring and deploying heterogeneous multigenerational resources to achieve persistent SCA (Barney and Hesterly 2013).

We have a very flexible organisational culture [that] allows us to have a strategy and plan with clear vision, [when we] follow its implementation day-by-day. We spend plenty of time together with our employees, than we spend [time] with our families, so we understand each other clearly. (AD)

The old must teach the young in a very competitive environment; this part of our culture [requires] incessant learning. (MA)

We are more and more competitive due to a supportive infrastructure, equipment and great talent at our headquarters in the Gulf [who] created a supportive environment. (BG)

The managers stated that their work culture was supportive for continuous learning and positive communication due to supportive infrastructure, equipment and great talent. This finding corroborates the empirical research by Barney and Delwyn (2007), which indicated that organisational capabilities comprise reporting structure and management control systems that provide effective utilisation of internal resources and capabilities. Similarly, other empirical conclusions have found that solid interpersonal resources depend on several organisational elements, including managerial support and internal and external communication (Palmatier et al. 2006); however, the fourth criterion of the RBV, organisation, requires some adaptation to support diverse abilities, processes and strategies to facilitate resource utilisation processes and policies that enable resource 'exploitation at the exchange versus firm level of analysis' (Kozlenkova et al. 2014, p. 2).

It is evident from the above analysis that banks' abilities to utilise resources and capabilities to achieve SCA is questionable. Even though VRIO resources are evident, organisational support and an environment that fosters innovative strategies and approaches to managing heterogeneous multigenerational workforces are also necessary. The real significance of these resources may exist in the way that managers of private banks in Egypt integrate, reconfigure and gain assets when handling opportunities.

\subsubsection{Theme 1: Gaps, Differences and Conflicts Among Generations}

Differing communication patterns among generations and generational conflict in the use of technology create communication barriers among generational cohorts. These two subthemes require manager to bridge communication gaps. According to the RBV, heterogeneous multigenerational workforces are linked to Dynamic managerial capabilities (DMC), defined as 'the capabilities with which managers build, integrate, and reconfigure organizational resources and competences' (Adner and Helfat 2003, p. 1012). As such, the major contribution of the current research is how DMC can be utilised in heterogeneous workplaces to achieve SCA.

\subsubsection{Communication Among Generations}

Participants' feedback about communication barriers among multigenerational employees confirmed the conclusions of Church and Rotolo (2013) that millennials, while technologically savvy and effective multitaskers, lacked oral, written and interpersonal communication skills.

For instance, old employees tend to be more resilient and patient with our customers than their young colleagues. (MA)

Young employees prefer working on their PCs, relying on visual devices, texting, messaging, etc. While old employee prefer to printout papers, ask for face-to-face meetings and feedback and mostly handwrite (DB).

Millennials want to achieve quick success; they want to get things done in a short time, but we are dealing with people's money. They seem to have low risk accountability, lack of communication skills with their peers, make unpremeditated decisions and come to conclusions without enough thinking. (AB) 
The findings corroborate those of Lancaster and Stillman (2002), who found that Baby Boomers often had high levels of communication when reciprocating information and they emphasised formal feedback mechanisms. Thus, organisational support must be provided to bridge communication gaps among generations, which can be challenging for managers, who must provide effective management, teamwork and leadership (Mayo et al. 2012).

\subsubsection{Generational Conflict and the Use of Technology}

The interviewees reported that conflicts arose in the workplace due to different styles of communication and the use of technology by different cohorts. Work conflict can occur due to work-life balance problems, poor communication and technology-use differences between cohort groups (Hillman, 2014).

Of course we have conflicts between cohorts in terms of using technology. (MA)

[We] have conflicts among old and young employees in terms of using technology; for instance, young employees prefer working on their PCs, relying on visual devices, texting, messaging, etc. While old employees prefer to printout papers, asking for face-to-face meetings and mostly handwrite. (DB)

The young learn technology applications quicker than the old employees; they want to achieve quick success and want to get things done in a short time. $(\mathrm{AB})$

These findings are consistent with empirical findings that Generation $\mathrm{X}$ and $\mathrm{Y}$ workers, who grew up with fast-paced technology, were less accustomed than Baby Boomers to learning through interaction. Mencl (2014.p.259) found that the use of technology, such as email and texting, was a primary communication method among Millennials and Generation X workers, this translates to a desire to receive detailed feedback from their supervisors on a frequent basis which encourages managers to provide instant and recurrent feedback to these workers. To increase productivity, organisational leaders might be requested to qualify Baby Boomers with enhanced training to retain their involvement in technology-based communication (Volkom et al. 2014). Based on the RBV, resource heterogeneity, resource assignment, accumulation and deployment determine SCA (Kostopoulos et al. 2002), linking heterogeneity to managerial capabilities to improve firms' performance (Helfat and Martin 2015). Thus, heterogeneous multigenerational workforces require DMC to integrate, deploy and reconfigure assets to generate value through the development and bundling of assets that affects "firms' abilities and achieve SCA.

\subsection{Theme 2: DMC Utilising Heterogeneity to Achieve SCA}

DMC include mentoring, training, supporting teamwork, transferring knowledge, fostering learning culture and providing coaching that encourages learning and feedback. Such capabilities are required to effectively utilise multigenerational workforces as a heterogeneous DMC and skills (Table 2).

\subsubsection{Deploying and Mentoring Employees and Building Teams to Retain Heterogeneity and Achieve SCA}

The results of this study are in accordance with the findings of Stumpf (2014) that organisational leaders who assist employees to improve job-related abilities aid organisations in refining effective deployment of employees, as well as mentoring, training, team building and productivity. Encouraging teamwork can help in lightening gaps triggered by generational differences (Lyons and Kuron 2014). These findings confirm empirical research that strengthening mentoring, training and coaching is fundamental to team building among internal talent (Festing and Schafer 2013).

My role is to deploy our employees based on their task-related skills; for instance, I allocate those who have responsibilities and commitments towards our bank in terms of their punctuality, honesty and self-determination as tellers and those who have communication skills as customer services. (MA)

I'm not only deploying a task but also I do monitoring our employees' behaviours, attitudes, and following- up tuitions with them on- the job and involving in their daily work activities for guidance and providing feedback to our staff so as to get the most benefits and long-lasting best performance and team building. (AD)

I have to deploy them differently on a daily basis; thus, customers will trust us, as a team, to achieve our competitive advantage. My main duties here are to teach, guide, support, monitor, coach, listen and explain and give feedback. (AB)

Thus, DMC are needed to deploy multigenerational heterogeneous resources by monitoring and creating teams.

4.2.2 Training, Transferring Knowledge, Fostering a Learning Culture and Coaching to Retain Heterogeneity and Achieve SCA

According to Long and Perumal (2014), managerial leaders implement training to improve deficiencies in abilities that arise from Baby Boomers retiring and encourage internal staff to generate competitive advantages against rivals. 
I send our employees for training and courses from specialists according to their defaults areas of knowledge so as to benefit them, and in turn, they will benefit us. I also summon experts from overseas to convey their expertise to our employees in different aspects of their assigned tasks to be able to act in their allocated posts properly. (MA)

I retrain them, guide them, and qualify them again and again in order to retain them; we do not dispose of our staff easily. (AD)

I send staff of all ages for training, testing, seminars, academic debates and conferences to be aware and updated with the most recent developments of banking system, and I summon experts to test their absorbed knowledge and how it can be utilised for new services or products. If [we do] not [do this], we will be excluded from the International Standard Basel 2, which will result in lost customers, reputation and jobs. (AB)

The old must teach the young in a very competitive environment; this is part of our culture of incessant learning. (WH)

Previous research found that training schemes aid managers in generating organisational modifications to develop and cope with augmented managerial requirements (Alasadi and Sabbagh 2015). Organisations that set up mentoring schemes to incorporate new employees with the existing workforce may achieve a better work environment (Cloutier et al. 2015). The findings also illustrate the role of transferring knowledge among employees and fostering a culture of continuous learning in the workplace among heterogeneous workforces. Consequently, as knowledge moves from retiring Baby Boomers to younger generations, business managers might be required to encourage employee interactions to retain young employees (Burch and Strawderman 2014). The findings also corroborate those of Salb (2015), who found that some managers seek to retain Baby Boomers to also retain the advantages of their professional capabilities and knowledge capital. Thus, training, transferring knowledge, foster a learning culture and coaching is DMC for retention of multigenerational workforces and for improving workers' skills to achieve organisational aims.

4.2.3 Listening, Encouraging Learning, Asking for Feedback and Providing Guidance and Support to Retain Heterogeneity and Achieve SCA

Gursoy et al. (2013) argued that managers must recognise the characteristics of each generation and their value differences to create and maintain workplaces that encourage inter-generational collaboration, communication, leadership and motivation. The managers of private banks in Egypt emphasised the significant role of their abilities and skills in recognising differences among heterogeneous multigenerational groups and addressing these differences by listening, encouraging learning, asking for feedback and providing guidance and support to achieve SCA.

I'm very keen to compromise by asking for feedback and listening to them; I encourage them to learn from each other, and I have an open-door policy for instant involvement so as not to affect working conditions. (AD)

I manage them by listening, encouraging learning and asking for incessant feedback and progress. I know how to teach, train, coach and prepare our staff to deal with our daily problems; we invest in them. (MA)

My main duties here are to teach, guide, support, monitor, coach, listen, explain and seek feedback; I cannot judge any employee without teaching him or her first. (DB)

The managers confirmed the recommendations of Al-Asfour and Lettau (2014) that senior leaders should spread innovative and advanced strategies for training and promoting new leaders to govern multigenerational workforces by inspiring employees to work together and by increasing team training so employees can leverage their skills. This involves searching for solutions during training to increase collaboration and communication. The research findings also agree with Ferri-Reed (2012b); leaders need to adopt certain skills and dynamic capabilities to manage multigenerational workforces effectively. These include the ability to be flexibility and allow for sufficient spare time, promoting better knowledge and skill building, bundling various communication methods to allow for dissimilar formats of communication, encouraging team task participation, seeking feedback and stablishing group collaboration.

Thus, DMC moderate the VRIO model for achieving SCA. The outcome of the current research shows that resources that are simply are valuable, inimitable and organised are not sufficient for achieving SCA; however, DMC that comprises 'asset orchestration' (Helfat et al. 2007, p. 24), including reconfiguration of assets, creates value through the development and bundling of assets that affect 'firms' abilities to adapt to changing conditions in their industry environments' (Sirmon and Hitt 2009, p. 1376). Thus, the VRIO model should be revised to incorporate moderating DMC to support VRIO resources to achieve SCA (Figure 2). 


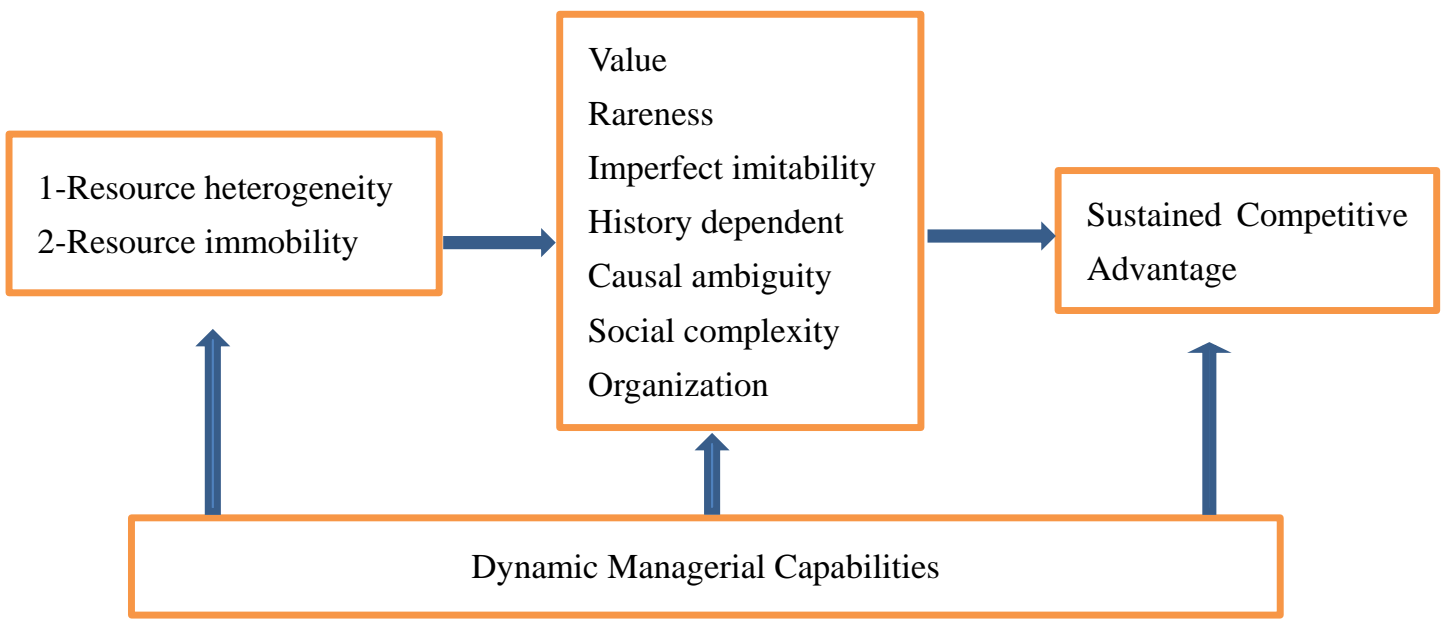

Figure 2. Dynamic managerial capabilities as a moderator and key component for supporting the VIRO model for achieving sustainable competitive advantage

Although the literature focuses on SCAs stemming from VRIO resources and stipulates that only resources that are naturally intangible fit into these principles, the role of DMC has been underestimated. The current research demonstrates that DMC moderate the VRIO framework for managing heterogeneous multigenerational workforces at private banks in Egypt. DMC allow senior managers to bring about 'integration, and, when required, reconfiguration and transformation - all aimed at sensing and seizing opportunities as markets evolve' (O'Reilly and Tushman 2008, p. 189), which explains why some firms outperform others (Kamasak 2017).

\section{Conclusion and Further Research}

Multigenerational workforces are a fact, and each generation has distinctive values, strengthen, weaknesses and abilities. Employing multigenerational workforces generates both opportunities and challenges for managers, who are required to develop techniques and new skillsets among these workforces to achieve organisational aims (Gursoy et al. 2008). They need to recognise opportunities and continual train workforce to shape staff competencies and to ensure flexibility and adaptable learning among employees.

General Managers' dynamic abilities are necessary for supporting the components of the VRIO to achieve SCAs, which also require innovative strategies to meet the challenges of rapidly changing industries. These results highlight that human resource specialists and academics need to better understand the increasing complications among multigenerational and heterogeneous workforces to offer support and training to executives. Additionally, resource idiosyncrasy, deployment, utilisation and organisation require DMC; thus, future qualitative research should be conducted to identify additional moderating and mediating effects that might exist among these capabilities in relation to organisational performance and the SCAs, as recommended by Kamasak (2017).

\section{Limitations}

One limitation of the research was that the sample included only seven general managers working in private banks in Egypt. In addition, there was difficulty in accessing these general managers and scheduling interviews because they were very busy. Another limitation of the research was that the data did not contain information regarding race, ethnicity or disability among participants, as respondents indicated that these are the most important side of their identity. An additional limitation was that the results only reflected the perspectives of the participating managers and not other executives from the administrative board. Thus, outcomes and findings of other research on public banks throughout Egypt might vary from those of this study.

\section{References}

Acosta, P. S., Colomo-Palacios, R., \& Loukis, E. N. (2011). A review of the RBV of the firm within the e-Business literature: What's next?. Interdisciplinary Journal of Research in Business, 1(1), 45-52

Adner, R., \& Helfat, C. E. (2003). Corporate effects and dynamic managerial capabilities. Strategic Management Journal, 24, 1011-1025. https://doi.org/10.1002/smj.331

Alasadi, R., \& Al-Sabbagh, H. (2015). The role of training in small business performance. International Journal of Information, Business and Management, 7, 293-311. 
Al-Asfour, A., \& Lettau, L. (2014). Strategies for leadership styles for multigenerational workforce. Journal of Leadership, Accountability and Ethics, 11, 58-70.

Apelbaum, E., Gerstner, E., \& Naik, P. (2003). The effects of expert quality evaluations versus brand name on price premiums. Journal of Product \& Brand Management, 12(3), 154-165. https://doi.org/10.1108/10610420310476915

Barney, J. (1991). Special Theory Forum: The Resource-Based Model of the Firm: Origins, Implications, and Prospects. Journal of Management, 17(1), 97. https://doi.org/10.1177/014920639101700107

Barney, J. B., \& Delwyn, C. N. (2007). Resource-Based Theory: Creating and Sustaining Competitive Advantage. Oxford: Oxford University Press.

Barney, J. B., Ketchen, D. J., \& Wright, M. (2011). The Future of Resource-Based Theory. Journal of Management 37(5), 1299-1315. https://doi.org/10.1177/0149206310391805

Barney, J., \& Arikan, A. (2001). The resource-based view: Origins and implications. In M. Hitt, R. Freeman, \& J. Harrison (Eds.), Handbook of Strategic Management (pp. 124-185). Oxford, UK: Blackwell.

Barney, J., \& Clark, D. (2007). Resource-based theory: Creating and sustaining competitive advantage. New York: Oxford University Press.

Barney, J., \& Hesterly, W. (2012). Strategic management and competitive advantage: Concepts and cases (4th ed.). New Jersey: Pearson.

Beck, J. B., \& Wiersema, M. F. (2013). Executive decision making: Linking dynamic managerial capabilities to the resource portfolio and strategic outcomes. Journal of Leadership \& Organizational Studies, 20, 408-419. https://doi.org/10.1177/1548051812471722

Beechler, S., \& Woodward, I. C. (2009). The global 'war for talent'. Journal of International Management, 15(3), 273-85. https://doi.org/10.1016/j.intman.2009.01.002

Behrstock-Sherratee, E., \& Coggshall, J. (2010, May). Realizing the promise of Generation Y. Educational Leadership, 28-34.

Beldona, S., Nusair, K., \& Demicco, F. (2008). Online travel purchase behavior of generational cohorts: a longitudinal study. Journal of Hospitality Marketing \& Management, 18, 406-420. https://doi.org/10.1080/19368620902799627

Berk, R. A. (2013). Multigenerational diversity in the academic workplace: Implications for practice. Journal of Higher Education, 28, 10-23.

Beyers, R. (2009). A five-dimensional model for educating the Net Generation. Educational Technology and Society, $12(4), 218-227$.

Brown, M. (2012). Responses to work intensification: Does generation matter?. International Journal of Human Resource Management, 23, 3578-3595. https://doi.org/10.1080/09585192.2011.654348

Burch, R., \& Strawderman, L. (2014). Leveraging generational differences to reduce knowledge transfer and retention issues in public administration. Public Administration Research, 3(2), 61-75. https://doi.org/10.5539/par.v3n2p61

Bureau of Labor Statistics in AARP. (2007). AARP Best Employers for Workers Over 50, 2007 Program Honorees. Retrieved from www.aarp.org/bestemployers

Caleb, P. (2014). How Diversity Works. Scientific American.

Cekada, T. L. (2012). Training a multigenerational workforce: Understanding key needs and learning styles. Professional Safety, 57, 40-44.

Cennamo, L., \& Gardner, D. (2008). Generational Differences in Work Values, Outcomes and Person-Organization Value Fit. Journal of Managerial Psychology, 23, 891-906. https://doi.org/10.1108/02683940810904385

Church, A. H., \& Rotolo, C. T. (2013). How are top companies assessing their high potentials and senior executives? A talent management benchmark study. Consulting Psychology Journal: Practice \& Research, 65, 199-223.

Cloutier, O., Felusiak, L., Hill, C., \& Pemberton-Jones, E. J. (2015). The importance of developing strategies for employee retention. Journal of Leadership, Accountability and Ethics, 12(2), 119-129.

Coulter, J. S., \& Faulkner, D. C. (2014). The multigenerational workforce. Professional Case Management, 19, 46-51. https://doi.org/10.1097/NCM.000000000000008 
Crampton, S. M., \& Hodge, J. W. (2007). Generations in the workplace: Understanding age diversity. The Business Review, 9(1), 16-22.

Crook, T., Ketchen, D., Combs, J., \& Todd, S. (2008). Strategic resources and performance: A meta-analysis. Strategic Management Journal, 29(11), 1141-1154. https://doi.org/10.1002/smj.703

Cummings, G. G., Spiers, J. A., Sharlow, J., Germann, P., Yurtseven, O., \& Bhatti, A. (2013). Worklife improvement and leadership development study: A learning experience in leadership development and planned organizational change. Health Care Manager, 38, 81-93. https://doi.org/10.1097/HMR.0b013e31824589a9

Debevec, K., Schewe, C. D., Madden, T. J., \& Diamond, W. D. (2013). Are today's millennials splintering into a new generational cohort? Maybe!. Journal of Consumer Behaviour, 12, 20-31. https://doi.org/10.1002/cb.1400

Eskilson, A., \& Wiley, M. (1999). Solving for the X: aspirations and expectations of college students. Journal of Youth and Adolescence, 28, 51-70. https://doi.org/10.1023/A:1021620508097

Eversole, B. A. W., Venneberg, D. L., \& Crowder, C. L. (2012). Creating a flexible organizational culture to attract and retain talented workers across generations. Advances in Developing Human Resources, 14, 607-625.

Ferri-Reed, J. (2012b). Blending different generations into a high-performance team. Journal for Quality and Participation, 35, 1-4.

Festing, M., \& Schafer, L. (2013). Generational challenges to talent management: A framework for talent retention based on the psychological-contract perspective. Journal of World Business, 2013(1).

Grant, R. M. (1991a). Contemporary Strategy Analysis: Concepts, Techniques, Applications. Cambridge, MA: Basil Blackwell.

Gursoy, D., Chi, C., \& Karadag, E. (2013). Generational differences in work values and attitudes among frontline and service contact employees. International Journal of Hospitality Management, 32(1), 40-48.

Gursoy, D., Maier, T. A., \& Chi, C. G. (2008). Generational differences: an examination of work values and generational gaps in the hospitality workforce. International Journal of Hospitality Management, 27(3), 448-458. https://doi.org/10.1016/j.ijhm.2007.11.002

Hahn, J. A. (2011). Managing multiple generations: Scenarios from the workplace. Nursing Forum, 46, 119-127.

Hansen, J. C., \& Leuty, M. E. (2012). Work values across generations. Journal of Career Assessment, 20, 34-52.

Harper, M., \& Cole, P. (2012). Member checking: Can benefits be gained similar to group theory?. The Qualitative Report, 17, 510-517.

Helfat, C. E., \& Martin, J. A. (2015). Dynamic managerial capabilities: Review and assessment of managerial impact on strategic change. Journal of Management, 4l(5), 1281-1312. https://doi.org/10.1177/0149206314561301

Hendricks, J. M., \& Cope, V. C. (2012). Generational diversity: What nurse managers need to know. Journal of Advanced Nursing, 69, 717-725. https://doi.org/10.1111/j.1365-2648.2012.06079.x

Hillman, D. (2014). Understanding multigenerational work-value conflict resolution. Journal of Workplace Behavioral Health, 25, 240-257. https://doi.org/10.1080/15555240.2014.933961

Hitt, M. A., Ireland, R. D., \& Hoskisson, R. E. (2001). Strategic Management: Competitiveness and Globalization (Concepts), Vol.4. Cincinnati, OH: South-Western Publishing.

Ismail, M., \& Lu, H. S. (2014). Cultural values and career goals of the Millennial generation: An integrated conceptual framework. Journal of International Management Studies, 9, 38-50.

Jennings, C. G., MacDonald, T. M., Wei, L., Brown, M. J., McConnachie, L., \& Mackenie, I. S. (2015). Does offering an incentive payment improve recruitment to clinical trials and increase the proportion of socially deprived an elderly participant?. Trials, 16(80), 1-9. https://doi.org/10.1186/s13063-015-0582-8

Joshi, A., Dencker, J. C., \& Franz, G. (2011). Generations in organizations. Research in Organizational Behavior, 31, 177-205. https://doi.org/10.1016/j.riob.2011.10.002

Jurkiewicz, C. L. (2000). Generation X and the public employee. Public Personnel Management, 29(1), 55-74.

Kamasak, R. (2017). The contribution of tangible and intangible resources, and capabilities to a firm's profitability and market performance. European Journal of Management and Business Economics, 26(2), 252-275.

Kilber, J., Barclay, A., \& Ohmer, D. (2014). Seven tips for managing Generation Y. Journal of Management Policy and Practice, 15, 80-91. 
Knight, R. (2016, June 24). "Managing People from 5 Generations." Generational Issues (2014): n. pag. Harvard Business Review.

Kostopoulos, K., Spanos, Y. E., \& Prastacos, G. P. (2002). The Resource-Based View of the Firm and Innovation: Identification of Critical Linkages. The 2nd European Academy of Management Conference. Stockholm.

Kozlenkova, I. V., Samaha, S. A., \& Palmatier, R. W. (2014). Resource based theory in marketing. Journal of the Academic Marketing Science, 42(1), 1-21. https://doi.org/10.1007/s11747-013-0336-7

Kraaijenbrink, J., Spender, J.-C., \& Groen, A. J. (2010). The Resource - Based View: A Review and Assessment of Its Critiques. Journal of Management, 36(1), 349-72. https://doi.org/10.1177/0149206309350775

Kupperschmidt, B. R. (2000). Multigenerational employees: strategies for effective management. The Health Care Manager, 19(1), 65-76. https://doi.org/10.1097/00126450-200019010-00011

Kuron, L. K. J. (2012). Managing an age diverse workforce. Equality, Diversity and Inclusion: An International Journal, 31(7), 690-691. https://doi.org/10.1108/02610151211263568

Lancaster, L. C., \& Stillman, D. (2002). When Generations Collide. Who They Are. Why They Clash. How to Solve the Generational Puzzle at Work . New York: Collins Business.

Langan, K. (2012). Training Millennials: A practical and theoretical approach. Reference Services Review, 40, 24-48.

Levitt, B., \& March, J. G. (1988). Organizational Learning. Annual Review of Sociology, 14(1), 319. https://doi.org/10.1146/annurev.so.14.080188.001535

Lockett, A., Thompson, S., \& Morgenstern, U. (2009). The development of the resource -based view of the firm: A critical appraisal. International Journal of Management Reviews, 11(1), 9-28.

Long, C. S., \& Perumal, P. (2014). Examining the impact of human resource management practices on employee turnover intention. International Journal of Business and Society, 15, 111-126.

Lyons, S., \& Kuron, L. (2014). Generational differences in the workplace: A review of the evidence and directions for future research. Jornal of Organizational Behavior, 35(S1), S139-S157. https://doi.org/10.1002/job.1913

Maritan, C. A., \& Peteraf, M. A. (2011). Invited Editorial: Building a Bridge between Resource Acquisition and Resource Accumulation. Journal of Management, 37(5), 1374-1389.

Marshall, B., Cardon, P., Poddar, A., \& Fontenot, R. (2013). Does sampling size matter in qualitative research? A review of qualitative interviews in IS research. Journal of Computer Information Systems, 11-22.

Mayo, M., Sanchez, J. I., Pastor, J. C., \& Rodriguez, A. (2012). Supervisor and co-worker support: a source congruence approach to buffering role conflict and physical stressors. International Journal of Human Resource Management, 23, 3872-3889. https://doi.org/10.1080/09585192.2012.676930

Mencl, J., \& Lester, S. W. (2014). More alike than different: What generations value and how the values affect employee workplace perceptions. Journal of Leadership \& Organizational Studies, 21(3), 257-272.

Morgan, N., Slotegraaf, R., \& Vorhies, D. (2009). Linking marketing capabilities with profit growth. International Journal of Research in Marketing, 26(4), 284-293. https://doi.org/10.1016/j.ijresmar.2009.06.005

Murphy, W. M. (2012). Reverse mentoring at work: Fostering cross-generational learning and developing millennial leaders. Human Resource Management, 51, 549-574. https://doi.org/10.1002/hrm.21489

Neuendorf, K. A. (2002). The Content Analysis Guidebook. Thousand Oaks: Sage Publications.

Newbert, S. L. (2007). Empirical research on the resource-based view of the firm: an assessment and suggestions for future research. Strategic Management Journal, 28(2), 121-46. https://doi.org/10.1002/smj.573

Newbert, S. L. (2008). Value, Rareness, Competitive Advantage, and Performance: A Conceptual-Level Empirical Investigation of the Resource-Based View of the Firm. Strategic Management Journal, 29, 745-768.

Noble, S. M., \& Schewe, C. D. (2003). Cohort Segmentation: An Exploration of Its Validity. Journal of Business Research, 56, 979-987. https://doi.org/10.1016/S0148-2963(02)00268-0

Normala, S. G., \& Dileep, K. M. (2013). Are "Y" Generation managers' attributes is associated with technology adoption behaviour?. Information Management \& Business Review, 5, 292-299.

O'Bannon, G. (2001). Managing our future: the generation X factor. Public Personnel Management, 30(1), 95-109.

O’Reilly, C. A., III, \& Tushman, M. L. (2008). Ambidexterity as a dynamic capability: Resolving the innovator's dilemma. Research in Organizational Behavior, 28, 185-206. https://doi.org/10.1016/j.riob.2008.06.002 
Palinkas, L. A., Horwitz, S. M., Green, C. A., Wisdom, J. P., Duan, N., \& Hoagwood, K. (2015). Purposeful sampling for qualitative data collection and analysis in mixed method implementation research. Administration and Policy in Mental Health and Mental Health Services Research, 42, 533-544.

Palmatier, R., Dant, R., Grewal, D., \& Evans, K. (2006). Factors influencing the effectiveness of relationship marketing: A metaanalysis. Journal of Marketing, 70(4), 136-153. https://doi.org/10.1509/jmkg.70.4.136

Peng, M. W., Meyer, K., \& Meyer, K. (2011) International Business. Cengage Learning London.

Penrose, E. T. (1959). The Theory of the Growth of the Firm. Oxford: Basil Blackwell.

Peteraf, M. A. (1993). The Cornerstones of Competitive Advantage: A Resource-Based View. Strategic Management Journal, 14(3), 179-191. https://doi.org/10.1002/smj.4250140303

Peteraf, M. A., \& Barney, J. B. (2003). Unraveling the Resource-Based Tangle. Managerial and Decision Economics, 24(4), 309-23. https://doi.org/10.1002/mde.1126

Rajput, N., Marwah, P., Balli, R., \& Gupta, M. (2013). Managing multigenerational workforce: Challenge for millennium managers. International Journal of Marketing and Technology, 3(2), 132.

Ricardo, D. (1817). On the Principles of Political Economy and Taxation. In P. Sraffa (Ed.), The Works and Correspondence of David Ricardo (1951, Vol. I). Cambridge: Cambridge University Press.

Salb, D. (2015). Using technology to retain baby boomers in the workforce. Computer and Information Science, 8, 180-185. https://doi.org/10.5539/cis.v8n3p180

Schultz, R. J., Schwepker, C. H., Davidson, M., \& Davidson, P. (2012). Boomers vs. Millennials: Critical conflict regarding sales culture, salesforce recognition, and supervisor expectations. International Journal of Business, Humanities and Technology, 2, 32-41.

Selvaraj, P. C. (2015). The effects of work Force diversity on employee performance in Singapore organisations. International Journal of Business Administration, 6(2), 17.

Sirmon, D. G., Hitt, M. A., Ireland, R. D., \& Gilbert, B. A. (2011). Resource Orchestration to Create Competitive Advantage Breadth, Depth, and Life Cycle Effects. Journal of Management, 37(5), 13901412.

Smola, K. W., \& Sutton, C. D. (2002). Generational differences: revisiting generational work values for the new millennium. Journal of Organizational Behaviour, 23(S1), 363-82. https://doi.org/10.1002/job.147

Stumpf, S. A. (2014). A longitudinal study of career success, embeddedness, and mobility or early career professional. Journal of Vocational Behaviour, 85, 180-190. https://doi.org/10.1016/j.jvb.2014.06.002

Teece, D. J., Pisano, G., \& Shuen, A. (1997). Dynamic capabilities and strategic management. Strategic Management Journal, 18(7), 509-33.

Twenge, J. M., \& Foster, J. D. (2010). Birth cohort increases in narcissistic personality traits among American college students, 1982-2009. Social Psychological and Personality Science, 1, 99-106.

Van Riel, A., de Mortanges, P., \& Streukens, S. (2005). Marketing antecedents of industrial brand equity: An empirical investigation in specialty chemicals. Industrial Marketing Management, 34(8), 841-847.

Volkom, M., Stapley, J., \& Amaturo, V. (2014). Revisiting the digital divide: Generational differences in technology use in everyday life. North American Journal of Psychology, 16, 557-574.

Wan, W. P., Hoskisson, R. E., Short, J. C., \& Yiu, D. W. (2011). Resource-Based Theory and Corporate Diversification. Journal of Management, 37(5), 1335-1368. https://doi.org/10.1177/0149206310391804

Weber, R. P. (1990). Basic Content Analysis (2nd ed.). Newbury Park, CA: Sage Publications.

Wernerfelt, B. (1984). A resource-based view of the firm. Strategic Management Journal, 5(2), 171-80.

Woodward, I. C., Vongswasdi, P., \& More, E. A. (2015). Generational diversity at work: A systematic review of the research. Working Paper Series 2015/48/OB. https://doi.org/10.2139/ssrn.2630650

Young, A. M., \& Hinesly, M. D. (2012). Identifying Millennials' key influencers from early childhood: Insights into current consumer preferences. Journal of Consumer Marketing, 29, 146-155. https://doi.org/10.1108/07363761211206393

Zeeshan, A., \& Iram, A. (2012). Generational diversity: Strategies to bridge the diversity gap. International Journal of Engineering and Management Sciences, 3, 315-318.

Zollo, M., \& Winter, S. G. (2002). Deliberate Learning and the Evolution of Dynamic Capabilities. Organization Science, 13(3), 339-351. https://doi.org/10.1287/orsc.13.3.339.2780 